\title{
Fiziksel Muayene Becerilerinin Geliştirilmesinde Yüksek Gerçeklikli Simülasyon Kullanımına Yönelik Hemşirelik Öğrencilerinin Görüşleri
}

\author{
Ayşe Demiray $\odot$, Selin Keskin Kızıltepe $\odot$, Nagihan İlaslan $\odot$, Ayşegül Açıl๑
}

Düzce Üniversitesi, Sağlık Bilimleri Fakültesi Hemşirelik Bölümü, Düzce, Türkiye

Ayşe Demiray, Dr. Öğr. Üyesi Selin Keskin Kızıltepe, Öğr. Gör. Dr Nagihan Illaslan, Araş. Gör. Ayşegül Açıl, Araş. Gör.

Illetişim:

Araş. Gör. Nagihan Illaslan Düzce Üniversitesi, Sağlık Bilimleri Fakültesi Hemşirelik Bölümü, Düzce, Türkiye Tel: +903805421141

E-Posta: nagihan-bitik@windowslive.com

\section{ÖZET}

Giriş: Öğrencilerin kazanmaları beklenen fiziksel muayene becerileri hemşirelik eğitiminin temel bileşenlerinden biri olarak değerlendirilmektedir. Çalışmanın amacl; Fiziksel Muayene Dersi uygulamasında akciğer, bağıısak ve kalp sesleri dinleme becerilerini yüksek gerçeklik düzeyine sahip simülatör ile gerçekleştiren hemşirelik öğrencilerinin simülasyon uygulamasına yönelik görüşlerini değerlendirmektir.

Gereç ve yöntem: Tanımlayııı tipte yapılan çalışma Fiziksel Muayene Dersi'ni alan 156 hemşirelik öğrencisi ile gerçekleştirilmiştir. Veriler araştırmacılar tarafından hazırlanan “Kişisel Bilgi Formu”, "Uygulamaya Yönelik Görüş Formu” kullanılarak toplanmıştır. Nicel veriler ortalama, standart sapma, ortanca, frekans şeklinde sunulmuştur. Verilerin analizinde Mann Whitney U testi kullanılmıştır.

Bulgular: Verilerin analizinde öğrencilerin \%58, $3^{\prime}$ ü Fiziksel Muayene Dersi'nin teorik ders saatini yeterli, \%63,5'i uygulamanın gerçekleştirildiği ortamı uygun, \%53,2'si uygulama için kullanılan simülatörü etkili ve yeterli ve $\% 71,2$ 'si uygulamalar sırasında öğretim elemanının desteğini yeterli olarak belirtmiştir. Ayrıca öğrencilerin $\% 64,7$ 'si uygulamalarda kullanılan simülatörde akciğer seslerini, \%51, $3^{\prime}$ ü bağırsak seslerini, $\% 71$, $8^{\prime} \mathrm{i}$ kalp seslerini rahatça duyabildiğini, \%46,2'si akciğer seslerini rahatça ayırt edebildiğini ve \%51,9'u simülatörde uygulama yapmanın gerçekmiş gibi hissettirdiğini belirtmiştir. Yine öğrencilerin \%21,2'sinin simülatör kullanımııı "gerçeğe yakın, uygun" olarak belirtmişlerdir.

Sonuç: Fiziksel muayene becerileri açısından donanımlı öğrenciler yetiştirmek amacıyla ders uygulamalarına gerçeklik düzeyi yüksek simülatörler, öğrencilerin bilgi ve beceri entegrasyonunu geliştirecek simülasyon senaryoları dahil edilmelidir.

Anahtar sözcükler: Hemşirelik, hemşirelik öğrencileri, fiziksel muayene, simülasyon

NURSING STUDENTS' VIEWS TOWARDS THE USE OF HIGH FIDELITY SIMULATION IN THE DEVELOPMENT OF PHYSICAL EXAMINATION SKILLS

\section{ABSTRACT}

Introduction: The physical examination skills of students are considered as one of the basic components of nursing education. The purpose of this study is to evaluate the nursing students' views about simulation applications who practice the sounds of the lung, intestine and heart sounds with high fidelity simulator.

Materials and methods: A total of 191 nursing students who took the Physical Examination Course in the descriptive type of study were targeted, but 156 students participated. The data were collected by using the "Personal Information Form" and "Opinion Form About Practice" prepared by the researchers. Quantitative data are presented as mean, standard deviation, median and frequency. Mann- Whitney $\mathrm{U}$ test was used in the analysis of the data.

Results: $58,3 \%$ of the students were satisfied with the theoretical hours of the Physical Examination lessons, $63,5 \%$ found the practice environment appropriate, $53,2 \%$ found the simulator effective and sufficient, $71,2 \%$ stated that the support of the lecturer was adequate during the applications. It was also found that in the simulator used in practice, $64,7 \%$ of students had heard lung sounds, $51,3 \%$ had heard intestinal sounds, and $71,8 \%$ had heard heart sounds easily; $46,2 \%$ stated that they distinguished the lung sounds easily and $51,9 \%$ felt that it was realistic. Again, $21,2 \%$ of them stated that the use of the simulator is "close to reality".

Conclusion: In order to train and equip students with physical examination skills, high fidelity simulators and scenarios that will develop the knowledge-skill integration of the students should be included in the courses.

Keywords: Nursing, nursing students, physical examination, simulation
Gönderilme Tarihi : 10 Eylül 2018

Revizyon Tarihi : 01 Ekim 2018

Kabul Tarihi : : 10 Ekim 2018 
G elişen bilim ve teknoloji ile birlikte ortaya çıkan hızlı değişimler sağlık alanına ve sağlık bakım ortamlarına yenilikçi yaklaşımlar getirmektedir. Bu durum bilgi ve psikomotor becerinin entegrasyonunu kapsayan hemşirelik eğitiminde, interaktif ve güncel öğretim tekniklerini gerektirmektedir $(1,2)$. Yaparak öğrenmeyi gerektiren psikomotor beceri kazanımı sürecinde yeteri düzeyde gelişmeyen beceriler ile klinik alanda deneyim kazanmaya çalışmak hasta güvenliği ve hasta hakları açısından risk oluşturabilmekte ve öğrencilerin klinik beceri gelişimlerini sınırlandırabilmektedir (3).

Temel amaçlarından biri hasta bakımını geliştirmek ve hasta güvenliğinin sağlanması amacıyla yetkin hemşireler yetiştirmek olan hemşirelik eğitiminde (4), hemşirelik becerilerinin gelişimi açısından klinik ortamlardan ziyade, ilk basamak olarak kullanılan hemşirelik beceri laboratuvarlarında yenilikçi öğretim metotlarının kullanımı artan bir öneme sahiptir $(4,5)$. İnteraktif yöntemlerden biri olan, eğitim sürecinde uzun yıllardır kullanılan ve kullanımı her geçen gün artan simülasyon tekniği ise gerçekçi, güvenli ve etkili bir öğrenme ortamı sunması dolayısıyla değerli bir öğretim stratejisidir $(4,6)$. Simülasyona dayalı öğretim, hastaya zarar verme ihtimali olmayan ortamlarda öğrenciye tekrarIı uygulama yapma fırsatı, sahip olduğu bilgi ve becerileri değerlendirebilme imkanı sunmaktadır. Bilgi ve becerilerin optimal düzeyde geliştirilmesi hasta bakımındaki hataları ve eksikleri azaltmaktadır (7-9).

Simülasyona dayalı öğretim; rol play, standardize hastalar, sanal gerçeklik, düşük ya da yüksek gerçeklik düzeyine sahip simülasyon gibi birçok farklı formata sahiptir. Düşük gerçeklik düzeyine sahip simülasyon tekniği durağan olup daha az gerçeklik sunabilirken, yüksek gerçeklikli simülasyon yöntemleri uygulamalara gerçek fizyolojik tepkiler verebilmekte ve maksimum düzeyde gerçeklik sunabilmektedir (10).

Literatür incelendiğinde simülasyona dayalı öğretim yönteminin öğrencilerin fiziksel muayene becerilerinin geliştirilmesi amacıyla kullanıldığı ve anlamlı sonuçlar ortaya koyduğu görülmektedir $(1,7,11)$. Öğrencilerin kazanmaları beklenen fiziksel muayene becerileri hemşirelik eğitim programlarının temel bileşenlerinden biri olarak değerlendirilmektedir. Çünkü bütüncül hemşirelik bakımı hastaların fiziksel olarak değerlendirilmesi ve sağlık öykülerinin alınmasına dayalı olarak bakımın planlanması ve uygulanmasını gerektirmektedir (12).

\section{Materyal ve metod}

Araştırma türü ve amacı

Tanımlayıcı tipte yapılan çalışmanın amacı, Fiziksel Muayene Dersi'ni almış olan ikinci sınıf hemşirelik öğrencilerinin akciğer, kalp ve bağırsak seslerini dinleme becerilerini yüksek gerçeklik düzeyine sahip simülatör ile gerçekleştirmelerine yönelik görüşlerini değerlendirmektir.

\section{Araştırma evreni ve örneklemi}

Araştırma evrenini 2017-2018 eğitim-öğretim yılı güz döneminde 01/03/2018-01/06/2018 tarihleri arasında bir devlet üniversitesinin Sağlık Bilimleri Fakültesi ikinci sınıfında öğrenim görmekte olan ve Fiziksel Muayene Dersi'ni alan toplam 191 hemşirelik öğrencisi oluşturmuştur. Evreni temsil edecek örneklem sayısı ise 191 öğrenciden \%95 güven sınırında \%5 kabul edilebilir hata ile 156 öğrenci olarak hesaplanmıştır.

\section{Veri toplama araçları}

Araştırma verileri, araştırmacılar tarafından hazırlanan, öğrencilerin tanımlayıcı özelliklerini içeren "Kişisel Bilgi Formu" ve "Uygulama Yönelik Görüş Formu" kullanılarak toplanmıştır.

\section{Kişisel Bilgi Formu}

Araştırmacılar tarafından literatür doğrultusunda hazırlanan Kişisel Bilgi Formu, öğrencilerin yaş, cinsiyet ve Fiziksel Muayene Dersi almadan önce akciğer, kalp ve bağırsak sesi dinleme eğitimi alıp almama ve eğer eğitim aldıysa nerede ve nasıl eğitim aldıklarına yönelik 3 adet sorudan oluşmaktadır.

\section{Uygulamaya Yönelik Görüş Formu}

Araştırmacılar tarafından hazırlanan "Uygulamaya Yönelik Görüş Formu", öğrencilerin Fiziksel Muayene Dersi kapsamında akciğer, kalp ve bağırsak sesleri dinleme becerilerini yüksek gerçeklik düzeyine sahip simülatör (Meti-Man Prehospital Simulator) ile gerçekleştirmelerine yönelik 3 adet açık uçlu sorudan oluşan 1 . kısım ve "Hiç katılmıyorum", "Katılmıyorum", "Kararsızım" ve "Katılıyorum" seçeneklerinden birini işaretleyecekleri 11 adet soru içeren 2. kısımdan oluşmaktadır. Formun ikinci kısmından öğrenciler en az 11, en fazla 44 puan alabilmektedir.

\section{Veri toplama}

Veriler veri toplama formları kullanılarak, Mart-Haziran 2018 tarihleri arasında araştırmacılar tarafından toplanmıştır. Katılımcıların veri toplama formlarını doldurabilmeleri için gereken süre 10-15 dakika arasındadır. 


\section{Araştırmanın etik yönü}

Çalışmanın yapılabilmesi için çalışmanın gerçekleştirildiği üniversitenin Klinik Araştırmalar Etik Kurulu'ndan (Etik onay no: 2018/39) ve Sağlık Bilimleri Fakültesi Hemşirelik Bölüm Başkanlığı'ndan yazılı izin alınmıştır. Çalışmaya katılım gönüllülük esasına dayalı olup, çalışmaya katılacak olan tüm öğrencilere araştırmanın amacı hakkında bilgi verilmiş çalışmaya katılan öğrencilerden sözlü onam alınmıştır.

\section{Verilerin Değerlendirilmesi}

Veriler bilgisayar ortamında SPSS 21.0 paket programı kullanılarak analiz edilmiştir. Nicel veriler ortalama, standart sapma, ortanca (minimum-maksimum), frekans (yüzde) şeklinde sunulmuştur. Verilerin istatistiksel analizinde Mann Whitney $U$ testi kullanılmıştır. Anlamlılık düzeyi $\mathrm{p}<0,05$ olarak alınmıştır.

\section{Çalışmanın sınırlııkları}

Çalışma verileri sadece Düzce Üniversitesi Sağlık Bilimleri Fakültesi Hemşirelik Bölümü ikinci sınıfta eğitim gören öğrencilerden elde edildiği için çalışma sonuçları Düzce Üniversitesi Sağlık Bilimleri Fakültesi Hemşirelik Bölümü ikinci sınıf öğrencileri ile sınırlıdır.

\section{Bulgular}

Araştırma bulguları tanımlayıcı istatistikler ve öğrencilerin görüşlerine yönelik gerçekleştirilen analizler şeklinde aşağıda sunulmuştur.

Çalışmaya katılan öğrencilerin yaş ortalamasının $20,36 \pm 1,29$ olduğu, \%93,6 ( $n=146)$ 'sının 19-21 yaş aralığında, \%68,6 ( $n=107)$ 'sının kadın olduğu, \%94,2 ( $n=147)$ 'sinin hemşirelik eğitimleri sürecinde Fiziksel Muayene Dersi almadan önce akciğer, kalp ve bağırsak sesi dinleme eğitimi almadıkları belirlenmiştir (Tablo 1). Bu konuda daha önce eğitim aldığını belirtenlerin \%5,8 (n=9)'inin ise Sağlık Meslek Lisesi'nde eğitim aldığı saptanmıştır.

Çalışmaya katılan öğrencilerin \%58,3 (n=91)'ü Fiziksel Muayene Dersi'nin teorik ders saatinin yeterli olduğunu, \%34,6 ( $n=54$ )'sı laboratuvar uygulama saatinin yeterliliği konusunda kararsız olduğunu, \%63,5 (n=99)'i uygulamanın gerçekleştirildiği ortamın uygun olduğunu, \%53,2 $(n=83)$ 'si uygulama için kullanılan simülatörün etkili ve yeterli olduğunu ve \%71,2 ( $n=111$ )'si uygulamalar sırasında öğretim elemanının öğrenciye verdiği desteğin yeterli olduğunu belirtmiştir. Aynı zamanda öğrencilerin \%64,7 ( $n=101)^{\prime} i$ uygulamalarda kullanılan simülatörde akciğer seslerini rahatça duyabildiğini, \%46,2 (n=72)'si akciğer
Tablo 1. Öğrencilerin tanımlayıcı özelliklerinin dağıımı $(N=156)$

\begin{tabular}{lccc} 
& & $\boldsymbol{n}$ & \% \\
\hline Yaş Grupları & $19-21$ & 146 & $\mathbf{9 3 , 6}$ \\
$\overline{\mathbf{x}}^{*} \pm S S^{* \star}=20,36 \pm 1,29$ & $22-27$ & 10 & 6,4 \\
& Kadın & 107 & $\mathbf{6 8 , 6}$ \\
Cinsiyet & Erkek & 49 & 31,4 \\
Eğitim Alma Durumu & Evet & 9 & 5,8 \\
Toplam & Hayır & 147 & $\mathbf{9 4 , 2}$ \\
* $^{*}$ : Aritmetik Ortalama, **S.S.: Standart Sapma & & $\mathbf{1 0 0}$ \\
\hline
\end{tabular}

seslerini rahatça ayırt edebildiğini, $\% 51,3(n=80)$ 'ü bağırsak seslerini rahatça duyabildiğini, \%71,8 (n=112)'i kalp seslerini rahatça duyabildiğini, \%51,9 (81)'u simülatörde uygulama yapmanın gerçekmiş gibi hissettirdiğini ve $\% 62,8$ (n=98)'i ise öğretim elemanı tarafından karışık olarak sunulan anormal akciğer seslerini ayırt ederek doğru şekilde cevap verebildiğini ifade etmiştir (Tablo 2).

Öğrencilerin Fiziksel Muayene Dersi ile ilgili görüşlerine yönelik maddelerinin madde puan ortalamaları Tablo 3'te verilmiştir. Öğrencilerin en yüksek puanı “Laboratuvar uygulamaları sırasında öğretim elemanının öğrenciye verdiği destek yeterliydi" $(3,60 \pm 0,72)$, ve "Fiziksel Muayene Dersi uygulaması kapsamında simülatörde kalp seslerini rahatça duyabildim" $(3,60 \pm 0,72)$, en düşük puanı ise "Fiziksel Muayene Dersi laboratuvar uygulama saati yeterliydi" $(2,44 \pm 1,00)$ ifadelerinden aldıkları belirlenmiştir. Çalışmada öğrencilerin Fiziksel Muayene Dersi ile ilgili görüşlerine yönelik maddelerin madde puan ortalamaları

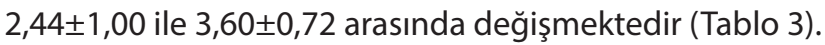

Öğrencilerin akciğer, bağırsak ve kalp seslerini dinleme becerileri için yüksek gerçeklik düzeyine sahip simülatör kullanımına yönelik görüşleri incelendiğinde, çalışmaya katılan öğrencilerin \%21,2 ( $n=33)^{\prime}$ sinin simülatör kullanımının olumlu yönünü "gerçeğe yakın, uygun olması" olarak belirttiği, \%35,3 ( $n=55$ )'ünün uygulamalarda simülatör kullanımının olumsuz bir yönünün olmadığını ifade ettiği ve \%42,9 (67)'unun ise "uygulama saatinin arttırılması" şeklinde öneride bulunduğu görülmüştür (Tablo 4).

Öğrencilerin tanımlayıcı özellikleri ile Fiziksel Muayene Dersi'ne yönelik görüşlerinin toplam puanları arasında yapılan analizlerde, öğrencilerin toplam puan ortalama-

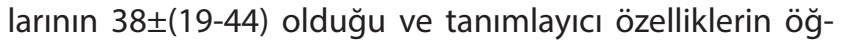
rencilerin görüşleri üzerinde etkili olmadığı belirlenmiştir ( $p>0.05)$ (Tablo 5). 


\section{Tablo 2. Öğrencilerin fiziksel muayene dersi ile ilgili görüşlerinin frekans dağılımları (N=156)}

\section{Sorular}

Fiziksel Muayene Dersi teorik ders saati yeterliydi

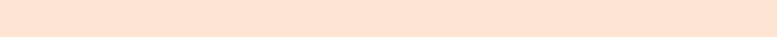

Fizsel Muayene Dersi laboraturar uygutama sati yeteriydi

Fiziksel Muayene Dersi laboratuvar uygulama saati yeterliydi

Hiç katılmıyorum

n

Katılmıyorum

11

Kararsızım

22

Katılıyorum

Hiç katılmıyorum

Katılmıyorum

Kararsızım

Katilıyorum

Fiziksel Muayene Dersi uygulamasının gerçekleştirildiği ortam uygundu

Hiç katılmıyorum

Katılmıyorum

Kararsızım

Katilıyorum

Fiziksel Muayene Dersi uygulaması için kullanılan simülatör etkili ve yeterliydi

Hiç katılmıyorum

Katılmıyorum

Kararsızım

Katilıyorum

32

32

91

34

44

$\mathbf{5 4}$

24

$\%$

7,1

14,1

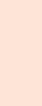

Laboratuvar uygulamaları sırasında öğretim elemanının öğrenciye verdiği destek yeterliydi

Hiç katılmıyorum

Katılmıyorum

Kararsızım

Katillyorum

4

4

13

40

20,5

$\mathbf{5 8 , 3}$

21,8

28,2

34,6

15,4 Fiziksel Muayene Dersi uygulaması kapsamında kullanılan simülatörde akciğer seslerini
rahatça duyabildim

Hiç katılmıyorum

Katılmıyorum

Kararsızım

Katlliyorum

99

2,6

8,3

25,6

63,5

7

4,5

7

4,5

25

16,0

41

26,3

53,2

Fiziksel Muayene Dersi uygulaması kapsamında kullanılan simülatörde akciğer seslerini rahatça ayırt edebildim

Hiç katılmıyorum

83

4

Fiksel Muayene Dersi uygulamaskapsamnda simutarde bagrsak sesterni ahatca

Fiziksel Muayene Dersi uygulaması kapsamında simülatörde bağırsak seslerini rahatça duyabildim

\section{Katılmıyorum}

Kararsızım

Katillyorum

Hiç katımıyorum

111

1,9

3

3

10,3

16

23,1

36

64,7

Fiziksel Muayene Dersi uygulaması kapsamında simülatörde kalp seslerini rahatça
duyabildim

Katılmıyorum

Kararsızım

Katılıyorum

Hiç katılmıyorum

5

5

5
17

10,9

62

39,7

46,2

72

9

5,8

9
12

5,8
7,7

35,3

55

80

51,3

Simühtörde uyguama yapmak bana gersekmis gibi hissetioni

Simülatörde uygulama yapmak bana gerçekmiş gibi hissettirdi

Katılmıyorum

Kararsızım

Katllyyorum

Hiç katılmıyorum

Katılmıyorum

Kararsızım

Katılıyorum

Hiç katılmıyorum

Katılmıyorum

Kararsızım

Katılıyorum

Toplam

seslerinden raller, whezing, ronküsü ayırt ederek doğru cevap verebildim

80

3

1,9

7,7

18,6

71,8

112

5,1

14,1

28,8

51,9

81

4

2,6

18,6

29 
Tablo 3. Öğrencilerin fiziksel muayene dersi ile ilgili görüşlerine yönelik maddelerinin ortalama, standart sapma ve ortanca puan değerleri

\begin{tabular}{|c|c|c|c|}
\hline Sorular & $\bar{x}^{*}$ & $S . S^{\star *}$ & Ortanca $\pm(\min -\max )^{\star \star *}$ \\
\hline Fiziksel Muayene Dersi teorik ders saati yeterliydi & 3,30 & 0,96 & $4,00 \pm(1-4)$ \\
\hline Fiziksel Muayene Dersi laboratuvar uygulama saati yeterliydi & 2,44 & 1,00 & $2,50 \pm(1-4)$ \\
\hline Fiziksel Muayene Dersi uygulamasının gerçekleştirildiği ortam uygundu & 3,50 & 0,76 & $4,00 \pm(1-4)$ \\
\hline Fiziksel Muayene Dersi uygulaması için kullanılan simülatör etkili ve yeterliydi & 3,28 & 0,89 & $4,00 \pm(1-4)$ \\
\hline Laboratuvar uygulamaları sırasında öğretim elemanının öğrenciye verdiği destek yeterliydi & 3,60 & 0,72 & $4,00 \pm(1-4)$ \\
\hline $\begin{array}{l}\text { Fiziksel Muayene Dersi uygulaması kapsamında kullanılan simülatörde akciğer seslerini } \\
\text { rahatça duyabildim }\end{array}$ & 3,51 & 0,76 & $4,00 \pm(1-4)$ \\
\hline $\begin{array}{l}\text { Fiziksel Muayene Dersi uygulaması kapsamında kullanılan simülatörde akciğer seslerini } \\
\text { rahatça ayırt edebildim }\end{array}$ & 3,29 & 0,79 & $3,00 \pm(1-4)$ \\
\hline $\begin{array}{l}\text { Fiziksel Muayene Dersi uygulaması kapsamında simülatörde bağırsak seslerini rahatça } \\
\text { duyabildim }\end{array}$ & 3,32 & 0,85 & $4,00 \pm(1-4)$ \\
\hline Fiziksel Muayene Dersi uygulaması kapsamında simülatörde kalp seslerini rahatça duyabildim & 3,60 & 0,72 & $4,00 \pm(1-4)$ \\
\hline Simülatörde uygulama yapmak bana gerçekmiş gibi hissettirdi & 3,28 & 0,89 & $4,00 \pm(1-4)$ \\
\hline $\begin{array}{l}\text { Uygulamanın son aşamasında öğretim elemanının simülatörden karışık sunduğu akciğer } \\
\text { seslerinden raller, whezing, ronküsü ayırt ederek doğru cevap verebildim }\end{array}$ & 3,39 & 0,88 & $4,00 \pm(1-4)$ \\
\hline
\end{tabular}

\section{Tartışma}

Çalışma sonuçları incelendiğinde çalışmaya katılan öğrencilerin \%58,3'ünün Fiziksel Muayene Dersi'nin teorik ders saatini yeterli olarak değerlendirdikleri, \%34,6'sının ise laboratuvar uygulama saatinin yeterliliği konusunda kararsız olduklarını belirttikleri görülmüştür. Aynı zamanda öğrenci görüşlerine yönelik madde puan ortalamaları incelendiğinde ise "Fiziksel Muayene Dersi laboratuvar uygulama saati yeterliydi" maddesinin en düşük madde puan ortalamasına sahip olduğu belirlenmiştir. Çalışma sonuçlarını destekleyen veya desteklemeyen farklı araştırma sonuçlarına rastlanmamış olup, Birks ve ark. (2014)'nın 53 akademisyen ile yaptığı çalışmasında, öğretilen $121 \mathrm{fi}-$ ziksel muayene becerisinin \%57'sinin öğrencilere uygulama yaptırılarak, \%24'ünün ise uygulama yaptırılmaksızın öğretildiği belirtilmektedir (13). Bu doğrultuda, çalışma sonuçları ışığında öğrencilerin daha fazla sayıda fiziksel muayene becerisini uygulama yaparak öğrenmek istedikleri belirtilebilir.

Literatür incelendiğinde fiziksel muayene gerçekleştirebilme yeterliliğinin profesyonel hemşirelik uygulamalarında önemli bir bileşen olduğu kabul edilmekle birlikte, öğrencilere ders kapsamında öğretilen içeriğin ihtiyaç duyulandan daha fazla olup olmadığı tartışılmaktadır $(14,15)$. Giddens (2007)'in hemşireler ile yaptığı çalışmasında öğretilen fiziksel muayene becerilerinin sadece \%30'unun rutin olarak uygulandığı, geri kalan becerilerin ise çok nadir veya hiç uygulanmadığı otaya koyulmuştur (16). Benzer şekilde Birks ve ark. (2014)'nın çalışmasında fiziksel muayene becerilerinin sadece \%34'ünün rutin olarak uygulandığı, \%35,5'inin hiç uygulanmadığı ve \%31'inin ise nadir olarak uygulandığı görülmüştür (13). Yine Giddens (2006)'in çalışmasında hemşireler tarafından en sıklıkla kullanılan fiziksel muayene becerilerinin kardiyovasküler ve solunum sistemi değerlendirmesi için kullanılan beceriler olduğu belirtilmiştir (17). Amerika, Avustralya, Kanada (18) ve Yeni Zelanda gibi (19) birçok ülkede hemşirelik eğitiminin temel bir bileşeni olan fiziksel muayene derslerinde, eğitimcilerin hemşirelik için gerekliliği yüksek fiziksel muayene yeterliliklerine odaklanmaları gerektiği belirtilmektedir (20).

Çalışmada öğrencilerin $\% 63,5^{\prime}$ inin uygulama ortamının uygun ve $\% 53,2$ 'sinin uygulamada kullanılan yüksek gerçeklik düzeyine sahip simülatörün etkili ve yeterli olduğunu belirttikleri bulunmuştur. Benzer şekilde Bremner ve ark. (2006)' nın hemşirelik öğrencileri ile yaptığı çalışmasında öğrenciler bilgisayarlı simülatör kullanılarak verilen fiziksel muayene beceri eğitiminin kendilerine olan güveni arttırdığını (\%62), mükemmel bir deneyim sağladığını (\%91) ve hemşirelik eğitiminde zorunlu olarak gerçekleştirilmesi gerektiğini (\%68) ifade etmişlerdir (21). Çalışma sonucundan farklı olarak yapılan diğer çalışmalarda hemşirelik öğrencileri, kliniğe çıkmadan önce gerçekleştirdikleri uygulamaların ve laboratuvar ortamlarının yeterli ve uygun olmadığını ve bu nedenle öğrendikleri teorik bilgileri klinik alanda yeteri düzeyde uygulayamadıklarını ve yetersizlik hissi yaşadıklarını ifade etmişlerdir $(22,23)$. Terzioğlu ve ark. (2012)'nın çalışmasında ise hemşirelik öğrencileri 
Tablo 4. Öğrencilerin simülatör kullanımı ile ilgili görüşleri $(N=156)$

\section{Sorular}

Herhangi bir fikri yok

Gerçeğe yakın, uygun olması

Uygulamanın konunun anlaşıırlığını arttırması

Klinikte karşılaşılabilecek durumlara yabancılığı azaltması

Kliniğe çıkmadan uygulama yapabilme avantajı

Uygulama becerisine katkı sağlaması

Simülatör kullanımının Sesleri ayırt edebilmeyi sağlaması olumlu yönleri

Gerçek hastadan duyulabilecek sesleri duyuyor gibi hissettirmesi

Klinikte karşılaşılabilecek durumlara yabancılığı azaltması+Uygulama becerisine katkı sağlaması+konunun anlaşılırlığını arttırması

Deneyim kazandırarak kendine güveni arttırması

Etkili bir öğretim yöntemi, eksikleri tamamlayabilme imkanı

Olumlu bir yönü yok

Stajda bu uygulamaları yaparken daha rahat olmayı sağlaması

Herhangi bir fikri yok

Sesler tam olarak ayırt edilmiyor

Öğrenci sayısı fazla, laboratuvar fiziki olarak küçük

Olumsuz bir yönü yok

Gerçek insan tepkisi olmadığı için gerçek uygulama kadar etkili değil

Tek simülatör var

Laboratuvar saati az

Simülatör kullanımııın olumsuz yönleri

\section{Simis}

Bağırsak sesleri ayırt edilemiyor

Akciğer sesleri net duyulmuyor

Simülatör çok ısınıyor, sesler bozuk gelebiliyor

Sesler duyulmuyor

Kalp seslerini duyamadım

Teknik arızalar olabiliyor

Biraz tedirginlik yaratıyor

Herhangi bir fikri yok

Uygulama saatinin arttırıması

Simülatör sayısının arttıııması

Uygulama saati ve simülatör sayısının arttırılması

Yeterince etkin olduğunu düşünüyorum

Önerim yok

Daha iyi simülatörler gerekli

Öneriler

Uygulamada ortamın sessizleştirilmesi, kişi sayısının azaltılması

Simülatörden gelen seslerin daha yüksek olmas

Vaka sunumu ve tartışması yapılabilir

Her uygulama, teorik dersinin arkasından yapılmalı

Laboratuvar hemşirelik öğrencilerine sürekli açık olmalı

Normal sesleri birbirimizde dinlemek etkin olurdu

Devam zorunluluğu olmamalı n

$\%$

3,8

21,2

33

19,9

31

5,8

3,8

10,3

10,3

12,8

0,6

9,0

0,6

0,6

1,3

5,1

10,9

17

9,6

35,3

7,7

9,0

5,8

1,3

0,6

1,3

5,1

5,8

0,6

0,6

1,3

6,4

42,9

67

9,6

14,7

23

2,6

7,7

2,6

3,8

2,6

0,6

1,9

0,6

3,2

0,6

100


Tablo 5. Öğrencilerin tanımlayıcı özellikleri ile fiziksel muayene dersi ile ilgili görüşlerinin toplam puanlarının karşılaşııııması

\begin{tabular}{lccc} 
Sorular & & $\begin{array}{c}\text { Ortanca } \pm \\
\text { (min-max)* }\end{array}$ & Test Değeri \\
\hline Cinsiyet & Kadın & $38 \pm(21-44)$ & $\mathrm{p}=0,366$ \\
& Erkek & $38 \pm(19-44)$ & $\mathrm{U}=2385,500$ \\
Yaş Grupları & $18-20$ & $38 \pm(19-44)$ & $\mathrm{p}=0,839$ \\
& $21-27$ & $38 \pm(22-44)$ & $\mathrm{U}=2378,500$ \\
Eğitim Alma Durumu & Evet & $37 \pm(24-44)$ & $\mathrm{p}=0,924$ \\
& Hayır & $38 \pm(19-44)$ & $\mathrm{U}=649,000$ \\
\hline
\end{tabular}

*Min: Minimum, Max: Maximum

simülasyon uygulamalarını yararlı olarak değerlendirmiş ancak kendilerini daha yeterli hissedebilmek için kullanılan maketlerin gerçeklik düzeylerinin yüksek olması gerektiğini önermişlerdir (24). Bu doğrultuda yüksek gerçeklik düzeyine sahip simülatörlerin öğrencileri klinik alanda karşılaşabilecekleri durumlara hazırlama, öğrencilerin yeterliliklerini ve öz güvenlerini arttırma konusunda etkili olduğu düşünülmektedir.

Uygulamada kullanılan simülatör üzerinde sesleri duyabilme ve ayırt edebilme durumları incelendiğinde, öğrencilerin \%64,7'sinin akciğer seslerini, \%51,3'ünün bağırsak seslerini ve \%71,8'inin kalp seslerini rahatça duyabildiğini belirttikleri görülmüştür. Aynı zamanda madde puan ortalamaları değerlendirildiğinde "Fiziksel Muayene Dersi uygulaması kapsamında simülatörde kalp seslerini rahatça duyabildim" maddesinin en yüksek madde puan ortalamalarından birine sahip olduğu görülmektedir. Çalışmamıza benzer başka çalışmalara ulaşılamamış olup, öğrencilerin en kolay kalp seslerini en zor ise bağırsak seslerini tanımlayabilmeleri dikkat çekmektedir.

Çalışmada ayrıca öğrencilerin \%62,8'inin uygulama sırasında karışık olarak sunulan akciğer seslerini doğru ayırt edebildiğini belirttikleri belirlenmiştir. Çalışma sonucuna benzer şekilde Tawalbeh (2017)' in yaptığı çalışmada kalp ve akciğerlere yönelik fiziksel muayene becerilerini simülasyon yöntemi kullanarak gerçekleştiren hemşirelik öğrencilerinin yeterlilik düzeyleri geleneksel öğrenme yöntemi kullanan öğrencilerden anlamlı olarak daha yüksek bulunmuştur (25). Aynı zamanda Multak ve ark. (2015)' nın çalışmasında kardiyopulmoner sistem fiziksel muayene ve tanılama becerilerinin öğreniminde simülasyon yöntemini kullanan tıp öğrencilerinin temel kardiyak oskültasyon bulgularını tanımlama ve doğru tanı koyabilme yeterliliklerinde anlamlı düzeyde artış saptandığı ifade edilmiştir (7). Yine Perlini ve ark. (2012)'nın tıp öğrencileri ile yaptıkları çalışmasında simülasyon temelli kardiyak oskültasyonun öğrencilerin kardiyak tanı koyabilme düzeylerini \%11,0'den \%72,0'e çıkardığı belirtilmiştir (11). Çalışma sonucundan farklı olarak Chen ve ark. (2015)'nın çalışmasında hemşirelik öğrencilerinin kardiyak ve solunum seslerine yönelik oskültasyon becerilerinin gelişiminde yüksek gerçeklik ya da düşük gerçeklik düzeyine sahip simülasyonun öğrenci performansında anlamlı bir farklılık oluşturmadığı ortaya koyulmuştur (26). Simülasyon uygulamalarından farklı sonuçların alınabilmesinin, simülasyon uygulamalarının sunduğu gerçeklik düzeylerinin ve uygulama sürecindeki farklııklardan (öğrencilerin uygulama becerilerinin öğretim elemanı tarafından gözlemi, video kayıt sistemlerinin kullanımı gibi) kaynaklanabileceği düşünülmektedir $(27,28)$.

Çalışmada simülasyon yönteminin kullanımına yönelik belirtilen olumlu görüşler değerlendirildiğinde, öğrencilerin çoğunluğu simülasyon uygulamasının gerçeğe yakın ve uygun olduğunu belirtmiş̧ir. Benzer şekilde Reilly ve Spratt (2007)'ın hemşirelik öğrencilerinin yüksek geçerlikli simülasyona dayalı öğrenmeye yönelik görüşlerini incelediği çalışmasında da öğrenciler simülasyon uygulamalarının yaşattığı gerçeklik hissine vurgu yapmıştır (29). Yine Sundler, Pettersson ve Berglund (2015)'un hemşirelik öğrencileri ile görüşme yöntemi kullanılarak gerçekleştirdiği çalışmasında yüksek gerçeklikli simülasyonun gerçekleştirilen deneyimi gerçekçi hale getirdiği belirtilmiştir (30). Smith ve Roehrs (2009)'in çalışmasında ise simülasyon uygulamalarının gerçeklik düzeyi ile uygulamalara katılan hemşirelik öğrencilerinin memnuniyet düzeyi ve özgüvenleri arasında anlamlı bir ilişki bulunduğu saptanmıştır (31). Literatür incelendiğinde gerçekleştirilen birçok çalışma sonucu benzer şekilde çalışma sonuçlarını desteklemektedir (11,32-34). Öğrencilerin simülasyon uygulamasına yönelik çoğunlukla gerçeklik düzeyine vurgu yapmasının, gerçekleştirilen uygulamaların gerçeklik düzeyinin öğrencilerin klinik ortama hazır olma durumlarını etkilemesinden kaynaklandığı düşünülmektedir. Simülasyon uygulamalarında kullanılan simülatörlerin gerçeklik düzeyi ve uygulama ortamının gerçek klinik ortama benzerliği arttıkça öğrencilerin kendilerine olan güvenleri, klinik karar verme becerileri ve psikomotor beceri yeterlilikleri de artmaktadır (35).

Öğrencilerin uygulamada simülasyon yönteminin kullanımına yönelik belirttikleri olumsuz görüşler incelendiğinde öğrencilerin \%35,3'ü herhangi bir olumsuz görüş belirtmemiştir. Benzer şekilde literatürdeki çalışmalar incelendiğinde çoğunlukla yüksek gerçeklik düzeyi bulunan simülatörlerin etkinliği vurgulanırken $(7,11,26,36)$, Terzioğlu ve ark (2012)' nın hemşirelik öğrencilerinin simülasyon yöntemine ilişkin görüşlerini incelediği çalışmasında öğrenciler maket 
ve mankenlerde oluşabilecek teknik sorunlara yönelik görüşlerde bulunmuşlardır (24). Nuzhat ve ark. (2014)' ın çaIışmasında ise öğrencilerin simülasyon uygulamalarına yönelik algıladıkları sorunlar arasında uygulamalara dahil olan ekip ve uygulama sürelerine yönelik belirtilen sorunlar, belirtilen diğer sorunlara göre daha yüksektir (37).

Çalışmada öğrencilerin uygulamalarda simülatör kullanımına yönelik yaptıkları öneriler incelendiğinde, öğrencilerin $\% 42,9^{\prime}$ u uygulama saatlerinin arttııımasını önermiştir. Çalışma sonucuna benzer şekilde Nuzhat ve ark. (2014)' nın çalışmasında öğretim elemanları \%71,4 düzeyinde simülasyon uygulamalarının başarıyla gerçekleştirilebilmesi için daha fazla süre gerekliliğini ifade etmişlerdir. Aynı zamanda hem öğretim elemanları hem de çalışmaya katılan öğrenciler simülasyonun değerlendirme aracı olarak da kullanılması konusunda görüş belirtmişlerdir (37). Ayrıca Najjar ve ark. (2015)'nın çalışmasında öğrenciler simülasyon uygulamalarının beceri laboratuarlarında gerçekleştirilen tekrarlı uygulamalardan daha öğretici olduğunu ve simülasyon uygulamalarının kendilerini daha yeterli hissetmelerine yardımcı olduğunu ifade etmiştir. Ayrıca aynı çalışmada öğrenciler her bir simülasyon uygulaması sonrası klinik deneyimlerini bütünleştirmeyi daha kolay bulmuştur. Çünkü öğrenciler daha fazla simülasyon uygulaması gerçekleştirdikçe eylemler arasındaki bağlantıları daha kolay ve hızlı şekilde kurabilmektedir (38). Bu konuda Cordeau (2012)'nun hemşirelik öğrencilerinin simülasyon deneyimlerine yönelik görüşlerini incelediği çalışmasında öğrenciler her simülasyon deneyiminin kendilerini klinik uygulamalara hazırlamada etkili olduğunu hissettiklerini belirtmişlerdir (39).

\section{Kaynaklar}

1. Eyikara E, Göçmen-Baykara Z. Effect of simulation on the ability of first year nursing students to learn vital signs. Nurse Educ oday 2018;60:101-6. [CrossRef]

2. Abe BY, Kawahara C, Yamashina A, Tsuboi R. Repeated scenario simülation to improve competency in critical care: A new approach for nursing education. Am J Crit Care 2013;22:33-40. [CrossRef]

3. Debourgh GA, Prion S. Using simulation to teach prelicensure nursing students to minimize patient risk and harm. Clinical Simulation Nursing 2011;7:47-56. [CrossRef]

4. Robinson BK, Dearmon V. Evidence-based nursing education: Effective use of instructional design and simulated learning environments to enhance knowledge transfer in undergraduate nursing students. J Prof Nurs. 2013;29:203-9. [CrossRef]

5. Edeer AD, Sarıkaya A. Hemşirelik Eğitiminde Simülasyon Kullanımı ve Simülasyon Tipleri. Hemşirelikte Eğitim ve Araştırma Dergisi 2015;12:121-5.

6. Bland AJ, Topping A, Wood B. A concept analysis of simulation as a learning strategy in the education of undergraduate nursing students. Nurse Educ Today 2011;31:664-70. [CrossRef]

\section{Sonuç}

Çalışma sonuçlarına göre hemşirelik öğrencilerinin yarısından fazlası fiziksel muayene dersinin teorik ders saatini, uygulama sırasında öğretim elemanı tarafından verilen desteği yeterli bulmuş, simülatörde uygulama yapmanın gerçekmiş gibi hissettirdiğini belirtmiş ve uygulamanın gerçekleştirildiği ortamı ve simülatörü etkili ve yeterli olarak değerlendirmiştir. Aynı zamanda öğrencilerin çoğunluğunun simülatörde akciğer, kalp ve bağırsak seslerini rahatça duyabildikleri ve anormal akciğer seslerini doğru ayırt edebildikleri belirlenmiştir. Bunun yanı sıra öğrencilerin çoğunluğunun simülatör kullanımına yönelik olarak simülatörün gerçeğe yakın ve uygun olduğunu belirttikleri, olumsuz görüş belirtmedikleri ve uygulama saatini yeterli bulmayarak uygulama saatlerinin arttırılmasını önerdikleri tespit edilmiştir.

Literatür ve çalışma sonuçları ışığında hemşirelik eğitiminde fiziksel muayene becerileri açısından yeterli öğrenciler yetiştirmek amacıyla ders uygulamalarına gerçeklik düzeyi yüksek simülatörlerin dahil edilmesi ve öğrencilerin bilgi ve beceri entegrasyonunu geliştirecek farklı simülasyon senaryolarının dahil edilmesi önerilmektedir. Aynı zamanda uygulama saatlerinin arttırılmasının fiziksel muayene becerilerinin geliştirilmesine katkı sağlayacağı düşünülmektedir. Bunun yanı sıra hemşirelik eğitiminde verilen fiziksel muayene dersleri ile ilgili yapılacak ileriki çalışmalar; literatüre öğrencilerin ders ve uygulamalar konusundaki görüşlerini, uygulamaların ve uygulama materyallerinin etkinliğini anlamada yardımcı olacak bulgular kazandıracaktır.
7. Multak N, Newell K, Spear S, Scalese RJ, Issenberg B. A MultiInstitutional Study Using Simulation to Teach Cardiopulmonary Physical Examination and Diagnosis Skills to Physician Assistant Students. J Physician Assist Educ. 2015;26:70-6. [CrossRef]

8. Berragan L. Simulation: an effective pedagogical approach for nursing?. Nurse Educ Today 2011;31:660-3. [CrossRef]

9. MacLean S, Kelly M, Geddes F, Dell P. Use of simulated patients to develop communication skills in nursing education: An integrative review. Nurse Educ Today 2017;48:90-8. [CrossRef]

10. Rosen KR. The history of medical simulation. J Crit Care 2008;23:15766. [CrossRef]

11. Perlini S, Musca F. Simulation-guided cardiac auscultation improves medical students' clinical skills: The Pavia pilot experience. Intern Emerg Med 2012;9:165-72. [CrossRef]

12. Endacott $R$, Jevon $P$, Cooper $S$. Clinical nursing skills- Core and advanced. Oxford: Oxford University Press 2009.

13. Birks M, James A, Chung C, Cant R, Davis J. The teaching of physical assessment skills in pre-registration nursing programmes in Australia: Issues for nursing education. Collegian 2014;21:245-53. [CrossRef] 
14. Fennessey A, Wittmann- Price RA. Physical assessment: a continuing need for 447 clarification. Nurs Forum, 2011;46:45-50. [CrossRef]

15. Giddens JF, Eddy L. A survey of physical examination skills taught in undergraduate nursing programs: are we teaching too much? J Nurs Educ. 2009;48:24-9. [CrossRef]

16. Giddens JF. A survey of physical assessment techniques performed by RNs: lessons for nursing education. J Nurs Educ 2007;46:83-7. [CrossRef]

17. Giddens J. Comparing the frequency of physical examination techniques performed by associate and baccalaureate degree prepared nurses in clinical practice: Does education make a difference?. J Nurs Educ, 2006;45:136-9. [CrossRef]

18. Lesa R, Dixon A. Physical assessment: implications for nurse educators and nursing practice. Int Council Nurs 2007;54:166-72. [CrossRef]

19. Zambas SI. Purpose of the systematic physical assessment in everyday practice: critique 452 of a "sacred cow". J Nurs Educ 2010;49:305-10. 453. [CrossRef]

20. Anderson B, Nix E, Norman B, McPike HD. An evidence based approach to undergraduate physical assessment practicum course development. Nurs Educ Pract 2014;14:242-6. [CrossRef]

21. Bremner MN, Aduddell K, Bennett DN, VanGeest JB. The use of human patient Simulator. Nurs Educ 2006;31:170-4. [CrossRef]

22. Kapucu S, Bulut $H$. Turkish nursing students' views of their clinical learning environment: A focus group study. Pak J Med Sci 2011;27:1149-53.

23. Schoening AM, Sittner AJ, Todd MJ. Simulated clinical experience: nursing students 'perceptions and educators' role. Nurs Educ 2006;31:253-8. [CrossRef]

24. Terzioğlu F, Kapucu S, Özdemir L, Boztepe H, Duygulu S, Tuna Z, ve ark. Simülasyon yöntemine ilişkin hemşirelik öğrencilerinin görüşleri. Sağlık Bilimleri Fakültesi Hemşirelik Derg 2012;19:16-23.

25. Tawalbeh LI. Effect of simulation on the confidence of university nursing students in applying cardiopulmonary assessment skills: A randomized controlled trial. J Nurs Res 2017;25:289-95. [CrossRef]

26. Chen R, Grierson LE, Norman GR. Evaluating the impact of high-and low-fidelity instruction in the development of auscultation skills. Med Educ 2015;49:276-85. [CrossRef]

27. Al-Ghareeb AZ, Cooper SJ, McKenna LG. Anxiety and clinical performance in simulated setting in undergraduate health professionals education: an integrative review. Clinical Simulation in Nursing 2017;13:478-91. [CrossRef]
28. Hengameh H, Afsaneh R, Morteza K, Hosein M, Marjan SM, Ebadi A. The effect of applying direct observation of procedural skills (dops) on nursing students' clinical skills: a randomized clinical trial. Global Journal of Health Science 2015;7:17-21. [CrossRef]

29. Reilly A, Spratt C. The perceptions of undergraduate student nurse of high-fidelity simulation-based learning: a case report from the University of Tasmania. Nurs Educ Today 2007; 27:542. [CrossRef]

30. Sundler AJ, Pettersson A, Berglund $M$. Undergraduate nursing students' experiences when examining nursing skills in clinical simulation laboratories with high-fidelity patient simulators: A phenomenological research study. Nurs Educ Today 2015;35:125761. [CrossRef]

31. Smith SJ, Roehrs CJ. High-fidelity simulation: factors correlated with nursing student satisfaction and self-confidence. Nurs Educ Perspect 2009;30:74-8.

32. Garrett B, MacPhee M, Jackson C. High-fidelity patient simulation: considerations for effective learning. Nurs Educ Perspect 2010;31:309-13.

33. Hoadley TA. Learning advanced cardiac life support: a comparison study of the effects of low-and high-fidelity simulation. Nurs Educ Perspect 2009;30:91-5.

34. Cantrell MA, Meakim C, Cash K. Development and evaluation of three pediatric-based clinical simulation. Clinical Simulation in Nursing 2008;4:e21-e28. [CrossRef]

35. Göriş S, Bilgi N, Bayındır SK. Hemşirelik eğitiminde simülasyon kullanımı. Düzce Üniversitesi Sağlık Bilimleri Enstitüsü Dergisi 2014;1:25-9.

36. Bingham AL, Sen S, Finn LA, Cawley MJ. Retention of advanced cardiac life support knowledge and skills following high-fidelity mannequin simulation training. Am J Pharm Educ 2015;79:12. [CrossRef]

37. Nuzhat A, Salem RO, Al-Sehri FN, Al-Hamdan N. Role and challenges of simulation in undergraduate curriculum. Medical Teacher 2014;36:S69-S73. [CrossRef]

38. Najjar, R., Lyman, B., Miehl, N. Nursing students' experiences with high-fidelity simulation. International Journal of Nursing Education Scholarship 2015;12:1-9. [CrossRef]

39. Cordeau, M.A. Linking the transition: A substantive theory of high-stakes clinical simulation. Advances in Nursing Science 2012;35:E90-E102. [CrossRef] 